\title{
O TRABALHO DO APENADO E A (DES)MARGINALIZAÇÃO DO DIREITO LABORAL
}

\author{
THE WORK OF THE PRISONER AND THE (UN) MARGINALIZATION OF \\ LABOR LAW
}

Laura Machado de Oliveira

\begin{abstract}
Mestra em direito do trabalho pela Universidade Federal do Rio Grande do Sul. Professora de Direito e Processo do Trabalho da Faculdade Dom Bosco de Porto Alegre. E-mail: lauramacoliver@hotmail.com
\end{abstract}

Recebido em: 28/03/2014

Aprovado em: 28/03/2016

Doi: $10.5585 / \mathrm{rdb} . v 13 i 6.136$

\begin{abstract}
RESUMO: O sistema de execução penal vigente no ordenamento jurídico brasileiro prevê a obrigatoriedade do trabalho do apenado à pena privativa de liberdade em caráter definitivo como forma de ressocialização da pessoa e para evitar o ócio carcerário, dentre outros fins. Tal trabalho sofre a não incidência dos direitos trabalhistas previstos na CLT, possuindo, o apenado, resguardo apenas a alguns benefícios previstos na legislação penal, além da remição da pena em razão do trabalho prestado. O Estado, ao possuir a custódia do condenado, deverá devolvê-lo para a sociedade como um cidadão capaz de coexistir em condições de convivência pacífica com os demais. Contudo, a conjuntura carcerária brasileira está calcando o caminho contrário, pois há o desrespeito à dignidade da pessoa humana, condição primordial para o tratamento de reabilitação.
\end{abstract}

Palavras-chave: Trabalho prisional; Trabalho obrigatório; Direito do Trabalho; Ressocialização.

\begin{abstract}
The current criminal enforcement system in the Brazilian legal system provides for compulsory work of the convict to deprivation of liberty on a permanent basis as a way of the person's rehabilitation and to avoid prison idleness, among other purposes. Such work suffers no impact of labor rights under the Labor Code, having the convict, guard just a few benefits under the criminal law, as well as redemption of the sentence because of the work performed. The State, has custody of the condemned should return it to society as a citizen able to coexist in peaceful coexistence conditions with others. However, the Brazilian prison environment is trampling the other way, because there is disrespect for human dignity, fundamental condition for rehabilitation treatment.
\end{abstract}

Keywords: Prison labor. Compulsory labor. Labor Law.Resocialization.

\section{O TRABALHO DO APENADO NO ATUAL CONTEXTO BRASILEIRO}

A ciência do direito sempre deverá ser abordada sob diversos enfoques, não apenas na área pormenorizada, específica na qual se concentram os principais efeitos, mas também nas demais searas em que porventura possam ocorrer respingos desses efeitos. É o que ocorre no 
campo do trabalho prisional, pois se verifica um forte ponto de encontro entre as disciplinas penalista e trabalhista, visto que o trabalho é realizado em ambiente prisional.

Adentrando no aspecto do direito penal,encontra-se artigo $5^{\circ}$, XLVI da CRFB as penas legalmente permitidas no Brasil..$^{1}$ Sem embargo, apesar desse rol de penas na Carta Magnabrasileira, demais direitos poderão ser suprimidos em decorrência da sentença condenatória que determinará a pena a ser aplicada no caso concreto, que será o demonstrado abaixo: a imputação de cumprimento da pena privativa de liberdade com a consequente restrição aos direitos trabalhistas. Portanto, encontra-se, novamente, em outro contexto histórico, a colisão entre a pena e o trabalho.

\title{
1.1. A CLASSIFICAÇÃO DO TRABALHO PRISIONAL
}

Primeiramente, antes de se adentrar no próprio mérito do trabalho prisional, é necessária a abordagem a respeito em favor de quem tal trabalho será prestado. Paracada situação (trabalho efetuado internamente ou chamado de intramuros/externamente ou chamado de extramuros, em benefício da iniciativa pública/privada), há particularidades, pois cada Estado federativo possui a sua forma de regulamentar a questão através de suas Secretarias de Segurança Pública, com o departamento competente para tanto, podendo ser realizado tanto o trabalho interno quanto o externo em seu benefício.Por exemplo, o trabalho interno é aquele efetuado para a própria manutenção do sistema carcerário, como em serviços para manutenção, limpeza, preparo de alimentação, etc da casa prisional.

Por seu turno, a respeito do trabalho prestado para a iniciativa privada, Rodrigo Garcia Schwarz explica:

O trabalho prisional consiste na prestação de serviços, por trabalhadores condenados a pena privativa de liberdade gerenciada por terceiros. Embora o trabalhador preso esteja sob a administração do Estado, através de um regime de direito público, muitas vezes a mão-de-obra [sic] prisional vem a ser utilizada por empresas privadas. (SCHWARTZ, 2011. p. 102)

\subsection{BENEFÍCIOS EDIREITOS RELATIVOS AOS CONDENADOS NA EXECUÇÃO LABORAL}

Inúmeras são as vantagens apontadas pela doutrina para o trabalho carcerário, dentre elas: o trabalho teria o fim de evitar o ócio dentro do sistema prisional, evitando rebeliões, impedindo a fragilização do sistema, assim como ajudando a desafogar os presídios superlotados, uma vez que a pena será diminuída com a remição dos dias trabalhados.Nesse sentido, Miguel Reale Júnior afirma:

\begin{abstract}
O trabalho constitui a espinha dorsal da execução da pena privativa de liberdade. A valorização do trabalho justifica-se, pois, se a ociosidade do desempregado constitui um desespero, não só por falta do salário essencial, mas também por não se ter o que fazer, mal do qual sofrem os aposentados, maior ainda é a aflição do preso, já destituído de todos os demais papéis sociais. Por essa razão a Lei de Execução Penal institui o trabalho como um dever e um direito do preso. [...]

$\mathrm{O}$ trabalho indica quem e como é a pessoa, que, em geral, orgulha do que faz. O trabalho fixa o horizonte da pessoa, a coloca no mundo social, a situa na sociedade. O trabalho para o homem preso é tanto ou mais importante do que para o homem livre, pois é necessário para a sua higidez mentale condição de dignidade humana,
\end{abstract}

\footnotetext{
${ }^{1}$ Art. $5^{\circ}$. CRFB. XLVI.A lei regulará a individualização da pena e adotará, entre outras, as seguintes:

a) privação ou restrição da liberdade;b) perda de bens;c) multa;d) prestação social alternativa;e) suspensão ou interdição de direitos;
} 
art. 28 da Lei de Execução Penal, imprescindível para fazer o tempo perdido passar e assim não ser tão perdido. [...]

O trabalho é instrumento de disciplina prisional e a dedicação ao mesmo é estimulada, não só pela punição como falta grave [...], como pela possibilidade de remição da pena [...]. Outorga-se um prêmio ao trabalho, tal o relevo que possui o exercício das tarefas [...]. (REALE JÚNIOR, 2003,p. 15-16)

O autor contempla todo o resgate como pessoa que o trabalho realiza, seja para a sua higidez mental, pelo seu orgulho e para a sua própria dignidade. Além disso, o labor ajuda na disciplina prisional.

\section{Luiz Antônio Bogo Chies aduz:}

O trabalho no cárcere, portanto, principalmente na origem do sistema punitivo prisional, possui uma função muito mais relevante do que a de somente evitar o ócio do recluso.

O trabalho prisional, como primeiro e mais direito elemento de vinculação entre a prisão e o sistema de produção do modelo socioeconômico capitalista, soma-se ao aspecto retributivo da reclusão para, a partir de atuações objetivas e subjetivas sobre o detento, a comunidade carcerária reclusa e a comunidade livre, repassar padrões e valores do sistema no qual o cárcere está inserido, manifestando este, assim, já a partir de sua gênese, aspecto de repasse ideológico no cumprimento de suas funções como aparelho a serviço do estado. (CHIES, 2000, p. 82)

De acordo com o autor, a sistemática adotada com o implemento do trabalho nas penitenciárias seria,além de evitar o ócio do detento, para demonstrar ao apenado o atual sistema econômico capitalista brasileiro. Além das vantagens acima referidas, há certos benefícios e direitos cabíveis aos condenados, como a remição da pena e a remuneração pelos serviços prestados.Cabe ressaltar que o preso não possui os direitos celetistas, 2 em razão disso serão estudados apenas os direitos concedidos na execução laboral de acordo com a LEP.

\subsubsection{REMIÇÃO}

Apontado como um dos maiores benefícios ao apenado, o trabalho, além de servir para a reinserção social e o aprendizado, ajuda na remição de sua pena, isto é, a cada três dias trabalhados, será reduzido um dia de sua pena, de acordo com o artigo 126, § 1o, II da LEP.3O preso, quando impossibilitado por acidente de prosseguir no trabalho ou nos estudos, continuará a beneficiar-se com a remição, consoante o § 4odo mesmo artigo. A remição deverá ser sempre declarada pelo juiz da execução, ouvidos o Ministério Público e a defesa.

\subsubsection{REMUNERAÇÃO}

A obrigação do pagamento ao preso foi introduzida pela Lei n.6.416, de 1977, seguindo as diretrizes expedidas pela ONU a respeito das Regras Mínimas para o Tratamento de Reclusos, em 1955, que estabeleceu também a forma de sua aplicação. Antes disso, nas penitenciárias em que o trabalho prisional era obrigatório, o preso não recebia remuneração e seu trabalho não era tutelado contra riscos nem amparado por seguro social. Nos

\footnotetext{
${ }^{2}$ Art. 28 LEP. O trabalho do condenado, como dever social e condição de dignidade humana, terá finalidade educativa e produtiva. $\S 2^{\circ} \mathrm{O}$ trabalho do preso não está sujeito ao regime da Consolidação das Leis do Trabalho. ${ }^{3}$ Art. 126 LEP. O condenado que cumpre a pena em regime fechado ou semiaberto poderá remir, por trabalho ou por estudo, parte do tempo de execução da pena. $\S 1^{\mathrm{o}} \mathrm{A}$ contagem de tempo referida no caput será feita à razão de: II - 1 (um) dia de pena a cada 3 (três) dias de trabalho. $§ 3^{\circ}$ Para fins de cumulação dos casos de remição, as horas diárias de trabalho e de estudo serão definidas de forma a se compatibilizarem. $\S 4^{\circ} \mathrm{O}$ preso impossibilitado, por acidente, de prosseguir no trabalho ou nos estudos continuará a beneficiar-se com a remição.
}

Revista de Direito Brasileira | São Paulo, SP | v. 13 | n. 6 | p. 167 - 189 | jan./abr. 2016 
estabelecimentos prisionais de qualquer natureza, os Poderes Públicos valiam-se das aptidões profissionais dos presos em trabalhos gratuitos.

Atualmente, a respeito do benefício da remuneração pelo trabalho prestado, encontrase o artigo 29 da LEP4 sobre a matéria. O pecúlio previsto no $\S 2^{\circ}$ do artigo 29 destina-se como um fundo para o preso se sustentar logo que posto em liberdade, um fundo para as suas necessidades de sobrevivência. Isto é, o pecúlio, na maioria dos casos, é ilusório, pois os valores pagos aos detentos na maioria das vezes são baixos, e tal valor deverá, primeiramente, atender às questões dispostas no $\S 1^{\circ}$. Assim, o pecúlio só será gerado quando sobrarem quantias monetárias relativas à remuneração do preso. Se o dinheiro for utilizado nas outras finalidades dispostas na lei e, consequentemente, não restarem valores, o pecúlio não será fomentado.

O Código Penal, em seu artigo 39,5 determina que o trabalho do preso seja sempre remunerado, além de que sejam garantidos os benefícios da Previdência Social. A remuneração sofrerá enfoques diversos a respeito do benficíario do labor, uma vez que é possível ser realizado em favor da administração pública ou para a iniciativa privada. $\mathrm{O}$ trabalho efetuado em prol da administração pública, é claro, será remunerado pela própria administração.

Já em relação a iniciativa privada, há custos menores de produção com o emprego dos apenados em função da não configuração da relação de emprego, portanto o trabalho do preso torna-se uma mão de obra muito barata para o empregador, porque se utiliza da força de trabalho nos doze meses do ano(pois não há direito a férias), não implica o pagamento do Fundo de Garantia do Tempo de Serviço (FGTS) e o pagamento do décimo terceiro salário, além do valor pago ao apenado ser menor do que o salário-mínimo nacional.

Dessa forma,comprova-se o caráter remuneratório do trabalho carcerário, introduzido no sistema capitalista com finalidade de lucro, através do empresariado que aplica a mão de obra para obtenção dos frutos da produção que serão comercializados logo que finalizados. É nesse momento que se visualiza a problemática da remuneração, mesmo sendo conferida com status de direito ao preso.

O Ministério Público do Trabalho (MPT) vem trilhando a proteção ao preso. No Estado do Paraná, o MPT ingressou com pedido de ação civil pública contra o Governo do Estado em razão das irregularidades no trabalho penitenciário. Há situações em que o serviço é prestado a terceiros (iniciativa privada), e os reclusos chegam a ter salários de $\mathrm{R} \$ 30,00.6$ Uma inspeção feita pelo MPT na fabricante de luvas Yelling mostrou que a empresa se utiliza de mão de obra carcerária com 90 presos, sendo que o total de empregados é 175. Ainda se constatou que os trabalhadores não possuem nenhum tipo de controle de saúde, sendo expostos a produtos químicos.

Dentre outras problemáticas que o MPT requer, encontram-se: exigência de atividades profissionais que tenham finalidades e caráter educativo, formativo, capacitador, profissionalizante; proibição de sanções disciplinares aos trabalhadores presos que se recusarem ao trabalho; proibição do uso de mão de obra carcerária para suprir carência de

\footnotetext{
${ }^{4}$ Art. 29 LEP. O trabalho do preso será remunerado, mediante prévia tabela, não podendo ser inferior a 3/4 (três quartos) do salário mínimo.§ $1^{\circ} \mathrm{O}$ produto da remuneração pelo trabalho deverá atender:a) à indenização dos danos causados pelo crime, desde que determinados judicialmente e não reparados por outros meios;b) à assistência à família;c) a pequenas despesas pessoais;d) ao ressarcimento ao Estado das despesas realizadas com a manutenção do condenado, em proporção a ser fixada e sem prejuízo da destinação prevista nas letras anteriores. $\S 2^{\circ}$ Ressalvadas outras aplicações legais, será depositada a parte restante para constituição do pecúlio, em Caderneta de Poupança, que será entregue ao condenado quando posto em liberdade.

${ }^{5}$ Art. 39 CP. O trabalho do preso será sempre remunerado, sendo-lhe garantidos os benefícios da Previdência Social.

${ }^{6}$ ASCOM/MPT-PR. Paraná tem presos trabalhando por salário de R\$30,00, afirma MPT-PR. MPT 9a Região, Curitiba, 6 fev. 2014. Disponível em: <http://www.prt9.mpt.gov.br/procuradorias/45-noticias-prt-curitiba/424parana-tem-presos-trabalhando-por-salario-de-r-30-afirma-mpt-pr-2>. Acesso em: 7 abr. 2014.
}

Revista de Direito Brasileira | São Paulo, SP | v. 13 | n. 6 | p. 167 - 189 | jan./abr. 2016 
seus quadros funcionais; proibição de transferir a terceiros a administração, manutenção e/ou operacionalização dos presídios.

Na reportagem "Indústria disputa trabalho barato do preso", da Folha de São Paulo Online, é abordado o valor pago aos presos, que gira em torno de $\mathrm{R} \$ 300,00$ por mês. Além do mais, há a notícia de diversas denúncias nos sindicatos das indústrias e de trabalhadores,do final de 2005, sobre a exploração do trabalho dos presos e a consequente concorrência desleal praticada pelas empresas que utilizam essa mão de obra. Conforme informado, um metalúrgico, por exemplo, custa cerca de $\mathrm{R} \$ 1.300,00$ por mês para a indústria, incluindo encargos sociais. Um preso, $\mathrm{R} \$ 400,00$ mensais, no máximo. Isto é, o preso custa para uma indústria, em média, de $25 \%$ a $30 \%$ do que custa o trabalhador. Uma ala da Penitenciária Feminina de São Paulo parece mais uma empresa do que uma penitenciária -cerca de 480 presas trabalham para indústrias, ou 75,5\% da população carcerária. (FERNANDES, 2006)

A esse fato, dá-se o nome de dumping social, fato que não está atrelhado únicamente ao trabalho carcerário, mas a qualquer relação em que o empresariado alfira lucros de uma forma desproporcional em comparação ao restante do mercado, ferindo o princípio da livre concorrência, previsto constitucionalmente. 7

Jorge Luiz Souto Maior,Ranúlio Mendes Moreira e Valdete Souto Severo conceituam tal acontecimento:

O "dumping social" constitui prática reincidente, reiterada, de descumprimento da legislação trabalhista, como forma de possibilitar a majoração do lucro e de levar vantagem sobre a concorrência. Deve, pois, repercutir juridicamente, pois causa um grave desajuste em todo o modo de produção, com sérios prejuízos para os trabalhadores e para a sociedade em geral. (MAIOR;SEVERO, 2014, p. 20-21)

Ou seja, o dumping social poderá ocorrer em qualquer ramo de atividade, com qualquer categoria envolvida, inclusive no trabalho carcerário.

A LEP não prevê um percentual que limite o uso da mão de obra presidiária nas empresas que se instalarem nas penitenciárias, apenas prevê, em seu artigo $36, \S 1^{\circ}$, o limite máximo de $10 \%$ de presos do total de empregados da obra ou serviços públicos, quando há o trabalho externo, e quando esse trabalho for prestado a favor da administração pública.Consoante ao tema, Jorge Luiz Souto Maior leciona:

\begin{abstract}
A confusão legislativa permitiu que se vislumbrasse no trabalho do preso uma simples alternativa de mão de obra barata, para atender a interesses tanto do próprio Estado (que, nesse aspecto, age como se estivesse defendendo um interesse da sociedade) e da iniciativa privada, para um desenvolvimento das relações capitalistas com menor custo. Chega a ser agressivo ver empresas, com fins econômicos, obtendo benefícios, ainda maiores dos que já têm, com a desgraça alheia, sob o falso argumento de que estão realizando um serviço de natureza social. O maior serviço de natureza social que alguém verdadeiramente pode prestar a outra pessoa é respeitar os seus direitos, respeitá-lo como cidadão por inteiro e não tratá-lo como cidadão pela metade, o que estaria permitido em razão da necessidade dessa pessoa.
\end{abstract}

A Constituição garante a todos o direito a dignidade, a isonomia, a cidadania, a função social da economia, a proibição de discriminação, etc.

A previsão da legislação penal, que nega direitos trabalhistas aos presos, põe em questão a própria função da pena.(MAIOR, 2008. p. 65- 66)

Dessa forma, apesar do caráter remuneratório do labor prisional, o trabalho obrigatório combinado com a baixa remuneração desenvolveram outras problemáticas. Verifica-se que a preocupação do trabalho carcerário não atinge apenas o próprio apenado com o seu desgaste excessivo, mas a sociedade, ocasionando a concorrência desleal e inclusive desemprego para a população não encarcerada. Visto isso, constata-se, principalmente, um fim econômico para

${ }^{7}$ Art. 170 CRFB. A ordem econômica, fundada na valorização do trabalho humano e na livre iniciativa, tem por fim assegurar a todos existência digna, conforme os ditames da justiça social, observados os seguintes princípios:IV - livre concorrência;

Revista de Direito Brasileira | São Paulo, SP | v. 13 | n. 6 | p. 167 - 189 | jan./abr. 2016 
o empregador, visando primeiramente, ao lucro, e apenas secundariamente, ao fim social do trabalho prisional.

O trabalho carcerário não é apenas isso, ele tem outro escopo. O operariado sofre com o abuso do poder diretivo, sendo que o apenado está ali para o aprendizado e a educação, deverá ocorrer uma contrapartida a esse trabalho prestado, o que não é verificado, bem pelo contrário, o apenado sai da prisão sem nenhuma garantia monetária (FGTS, por exemplo), apenas receberá o pecúlio (frisa-se novamente: se restarem quantias monetárias para o pecúlio), sem a qualificação necessária, pois muitas vezes o trabalho é meramente mecânico, além do desgaste físico e mental, pois ao preso não é conferido o direito às férias.

\subsubsection{PREVIDÊNCIA SOCIAL}

O preso possui direito à Previdência Social conforme os artigos 41 da LEP e 39 do Código Penal.8Dessa forma, o preso possui direito a todos os benefícios previdenciários dispostos na Lei n. 8.213 de 1991, desde que cumpridos os requisitos para a sua concessão. Porém, resta a dúvida a respeito de em qual tipo de segurado ele será enquadrado dentro do sistema, isto é, segurado empregado, segurado especial, contribuinte individual, etc. $\mathrm{O}$ artigo 11 da citada Lei, que faz o enquadramento dos segurados obrigatórios, não refere o trabalho do preso em nenhum de seus incisos.

Porém, o Regulamento da Previdência Social, Decreto n. 3.048 de 1999, elenca os segurados que poderão, facultativamente, filiar-se:

Art. 11 Decreto $n^{\circ}$ 3048/1999. É segurado facultativo o maior de dezesseis anos de idade que se filiar ao Regime Geral de Previdência Social, mediante contribuição, na forma do art. 199, desde que não esteja exercendo atividade remunerada que o enquadre como segurado obrigatório da previdência social.

$\S 1$ o Podem filiar-se facultativamente, entre outros:

IX - o presidiário que não exerce atividade remunerada nem esteja vinculado a qualquer regime de previdência social;

$\mathrm{XI}$ - o segurado recolhido à prisão sob regime fechado ou semi-aberto [sic], que, nesta condição, preste serviço, dentro ou fora da unidade penal, a uma ou mais empresas, com ou sem intermediação da organização carcerária ou entidade afim, ou que exerce atividade artesanal por conta própria.

§ 3으 filiação na qualidade de segurado facultativo representa ato volitivo, gerando efeito somente a partir da inscrição e do primeiro recolhimento, não podendo retroagir e não permitindo o pagamento de contribuições relativas a competências anteriores à data da inscrição, ressalvado o $§ 3$ - do art. 28.

O apenado será segurado facultativo, e não obrigatório. Assim, é necessário o interesse do apenado em contribuir para a Previdência Social. Como os presos no Brasil (a maioria) não sabem do seu direito de se tornar um segurado da Previdência, acabam por não se filiar ao sistema.

Por fim, quanto ao rol de direitos garantidos, atualmente, aos apenados, apesar de não se encontrarem amparados pelo direito trabalhista clássico, alguns são resguardados, como a jornada de trabalho, e o respectivo descanso semanal aos domingos de acordo com o artigo 33 da LEP.9

\footnotetext{
${ }^{8}$ Art. 41 LEP. Constituem direitos do preso:III - Previdência Social;Art. 39 CP. O trabalho do preso será sempre remunerado, sendo-lhe garantidos os benefícios da Previdência Social.

${ }^{9}$ Art. 33 LEP. A jornada normal de trabalho não será inferior a 6 (seis) nem superior a 8 (oito) horas, com descanso nos domingos e feriados.Parágrafo único. Poderá ser atribuído horário especial de trabalho aos presos designados para os serviços de conservação e manutenção do estabelecimento penal.
}

Revista de Direito Brasileira | São Paulo, SP | v. 13 | n. 6 | p. 167 - 189 | jan./abr. 2016 


\subsubsection{A RESSOCIALIZAÇÃO DO APENADO}

Um dos pontos assinalados, largamente, pela doutrina diz respeito à aplicação do trabalho carcerário, sobre o seu cunho ressocializatório. Sergio Francisco Carlos Graziano Sobrinho aborda o surgimento da ressocialização no contexto da pena:

A ideia de correção do apenado foi inicialmente difundida pela Escola Correcionalista que sustentava que o único fim da pena é a correção do delinquente, pela sua transformação interior. Suas proposições avançaram os limites da conciliação das teorias absolutas e relativas da pena, acabando por preconizar a remodelação completa do Direito Penal tradicional, a extinção da pena e a concentração de esforços dirigida ao idôneo tratamento dos delinquentes.

Assim é que, a partir do século XVIII, com as mudanças provocadas, principalmente, pela Revolução Francesa e Iluminismo, a pena de prisão passa a ocupar destacado espaço nos chamados países civilizatórios. A função de ressocialização do "delinquente" e sua correlata ideologia do tratamento são tratadas no âmbito da teoria da pena, sob a rubrica genérica de prevenção especial ou, mais especificamente, por prevenção especial preventiva.

[...] a pena passou a não ter apenas um sentido de retribuição, mas também de prevenir o crime. O fim da pena, para a teoria da prevenção especial positiva, passa a ter a conotação de ressocialização, consubstanciada na ideologia do tratamento, visando à reinserção social do indivíduo condenado, com a intenção de que ele passe a respeitar a lei.(GRAZIANO SOBRINHO, 2007, p. 71).

A ressocialização seria uma forma e um fim da pena. Seria uma forma de executá-la, assim como, após o seu cumprimento, seria contemplado o fim com a recolocação da pessoa à vida em sociedade. $\mathrm{E}$, fatalmente, uma das formas de atingir a ressocialização seria através do trabalho.

Do ponto de vista filosófico e pedagógico, Michel Foucault em seu livro Vigiar e Punir estabelece as vantagens do trabalho:

Essa pedagogia tão útil reconstituirá no indivíduo preguiçoso o gosto pelo trabalho, recolocá-lo-á por força num sistema de interesses em que o trabalho será mais vantajoso que a preguiça, formará em torno dele uma pequena sociedade reduzida, simplificada e coercitiva onde aparecerá claramente a máxima: quem quer viver tem que trabalhar. Obrigação do trabalho, mas também retribuição que permite ao detento melhorar seu destino durante e depois da detenção. [...] Entre o crime e a volta ao direito e à virtude, a prisão constituirá um "espaço entre dois mundos", um lugar para as transformações individuais que devolverão ao Estado os indivíduos que este perdera. (FOUCAULT, 1999, p. 141)

Foucault ainda afirma que a modulação temporal é imprescindível para a pena, pois de acordo com ele:

Consequentemente, utilidade de uma modulação temporal. A pena transforma, modifica, estabelece sinais, organiza obstáculos. Qual seria sua utilidade se se tornasse definitiva? Uma pena que não tivesse termo seria contraditória: todas as restrições por ela impostas ao condenado e que, voltando a ser virtuoso, ele nunca poderia aproveitar, não passariam de suplícios; e o esforço feito para reformá-lo seria pena e custo perdidos, pelo lado da sociedade. (FOUCAULT, 1999, p. 127)

Conforme FOUCAULT, 1999, p. 128: "tempo, o operador da pena". Todavia, para que haja efetivamente essa transformação da pessoa segregada para a posterior convivência com os demais, nada mais justo do que tratar-se esse sujeito como um ser dotado de direitos que fazem jus em existir mesmo ao longo da execução da pena. criminoso:

Salo de Carvalho, em seu viés criminal, aborda a finalidade da sanção imposta ao 
[...] a sanção estatal deve adquirir sentido positivo, promovendo não somente coação aos não desviantes (temor pela autoridade), mas fornecendo meios para que o criminoso não incorra novamente no delito e seja integrado na e pela comunidade. $\mathrm{O}$ exercício do direito de punir passa a ser norteado pela ideia de prevenção especial positiva, consolidando as teorias de ressocialização, recuperação e regeneração do criminoso elaboradas pela criminologia positivista (paradigma etiológico-causal). (CARVALHO, 2008, p. 103)

De acordo com o criminalista, para evitar novos delitos não bastaria o medo da punição, mas também é necessário oferecer meios adequados para que os apenados, futuramente, não voltem a delinquir, e a ressocialização é apontada como um meio para esse fim.

Laurita Vaz, sobre o assunto, declara:

O trabalho do preso é, indiscutivelmente, um dos grandes desafios do Terceiro Milênio. Não é mais possível a passiva aceitação da injustificável ociosidade em que vive a maioria dos presos que estão recolhidos nas Penitenciárias brasileiras, com maior gravidade daqueles que estão encarcerados nas Cadeias Públicas, onde o ócio é ainda maior. Como é de notório conhecimento, as Cadeias Públicas não dispõem de acomodações compatíveis nem de condições adequadas para abrigar e muito menos "proporcionar a harmônica integração social do condenado e do internado", objetivo da execução penal, que vem expressamente preconizado no artigo $1^{\circ}$, da Lei de Execuções Penais.

Com efeito, se ao homem livre de que qualquer apenação, o trabalho, de onde tira o seu sustento, por mais humilde que seja, o dignifica e ainda representa um dever moral e social, porque imputar ao preso a nociva ociosidade, reconhecida por todos como uma das causas geradoras de indisciplinas, fugas, reincidência, desestruturação familiar, motins e rebeliões nos Estabelecimentos Prisionais? Ademais, se o encarcerado não trabalha, a responsabilidade de sua manutenção recai exclusivamente no Estado, exigindo cada vez mais recursos financeiros para essa finalidade.

Criar nos Estabelecimentos Prisionais fontes de trabalho para ocupar o tempo do condenado e do internado, proporcionando-lhes sua reintegração social com dignidade é, sem dúvida, um dos maiores desafios do Estado, dos órgãos envolvidos com a execução penal, das autoridades e do cidadão, que também é responsável para que a pena em execução não seja desprovida do cárcere educativo e ressocializador que a lei lhe atribui. (VAZ, 2012, p. 19)

Laurita ressalta que o trabalho pautado nos ditames da ressocialização é um dos maiores desafios do Estado, pois harmonizar a forma e o objetivo da pena (que no caso é a ressocialização) com o trabalho é tarefa complicada de ser realizada.

Anabela Miranda Rodrigues ensina que, para que seja alcançada a ressocialização, deverá ocorrer a "participação" do detento:

Reconhece-se, assim, ao recluso, uma posição de sujeito da execução - enquanto participante ativo e com personalidade responsável no processo de (re)socializaçãoafastando uma visão das coisas que o tornava em mero destinatário passivo das normas, colocado na posição de objeto das preocupações de uma execução orientada por qualquer finalidade que fosse.

Por outro lado, evidencia-se a estrutura ressocializadora do tratamento, conformada pela participação do recluso, em último termo, dela dependente.

De fato, arranca-se aqui do reconhecimento da ideia de que a preparação para a vida em responsabilidade social é um processo cujo início se localiza já no decurso da própria execução; só assim existe uma real possibilidade de se alcançarem os objetivos pretendidos, no que a participação assume um papel de relevo.

Ela constituiu, assim, o pressuposto de um verdadeiro tratamento, sendo mesmo indispensável, já que não existe ressocialização sem ou contra a vontade do recluso.

O que permite o acentuar desta necessidade de participação é, por sua vez, o reforçar daquela ideia que rodeia a afirmação de um "direito" à ressocialização por parte do recluso. (RODRIGUES, 1999, p. 88-89) 
Logo, consoante ao defendido pela autora, é necessário que o apenado manifeste a sua vontade de modificar seus hábitos e que seja efetivamente ressocializado, pois não poderá haver "ressocialização forçada". No momento em que a sociedade o segregou do convívio com os demais, torna-se necessário que sejam disponibilizados meios para que ao fim de seu tratamento ele esteja apto a conviver com os demais. Assim, a melhor forma de ressocializar os detentos seria em condições similares às que os aguardam do lado de fora das prisões. Seria necessário despertar nos apenados a estima do trabalho tal qual realizado pelo homem livre. Em seguida, a autora persiste com a sua ideia, agora demonstrando como poderá ser realizada:

\begin{abstract}
Sublinha-se, a este propósito, por outro lado, que o regime de execução das penas privativas de liberdade de longa duração deve comportar uma aproximação crescente e progressiva à vida livre. A maior parte dos reclusos mostram-se gravemente desadaptados [sic] à vida em sociedade e não é isolando-os do mundo tolhendo- os, pois, no assumir das suas responsabilidades sociais - que se melhorará o seu futuro comportamento. Tanto mais que a sociedade se transforma a um ritmo tal que a separação recluso-sociedade terá tendência a acentuar-se se não for obstada através de medidas que a atenuem.(RODRIGUES, 1999, p. 92)
\end{abstract}

THOMPSON, 2002, p. 12-13 realiza um comparativo: "Parece, pois, que treinar homens para a vida livre, submetendo-os a condições de cativeiro, afigura-se tão absurdo como alguém se preparar para uma corrida, ficando na cama por semanas".Ou seja, conforme afirmado pelo autor, será mais fácil a chegada da estimada ressocialização do apenado quando o trabalho for realizado de forma similar ao trabalho livre. Tal conclusão é, praticamente, lógica, pois a melhor forma de preparar o indivíduo para a vida em sociedade é colocá-lo em situações parecidas com a vida que terá em sociedade.Inclusive, em relação à preparação para a volta da vida em sociedade.Porém, infelizmente, o Brasil não segue tal raciocínio, pois as condições de trabalho no cárcere estão longe daquelas do homem livre.

\title{
2. A MARGINALIZAÇÃO CELETISTA
}

Conforme demonstrado, o apenado que se encontra trabalhando possui poucos direitos trabalhistas em função de estar marginalizado da Consolidação das Leis do Trabalho (CLT).10Inicialmente, torna-se curioso o fato de o legislador considerar apenas a CLT como norma trabalhista, esquecendo-se da existência de leis esparsas (desvinculadas à CLT) que também tratam da relação de emprego, como é o caso do trabalho rural e doméstico. A doutrina e jurisprudência apontam diversos motivos para tal marginalização celetista, seja em função do trabalho do condenado possuir a finalidade educativa e produtiva (princípios os quais são encontrados no caput do mesmo artigo), ou pelo fato do trabalho prisional ser considerado obrigatório.

Porém, na exposição de motivos da LEP, mensagem n. 242 de 1983, encontra-se a razão pela qual existe a exclusão do trabalho do preso do rol das relações de emprego:

56. O Projeto conceitua o trabalho dos condenados presos como dever social e condição de dignidade humana - tal como dispõe a Constituição, no art. 160, inc. $\mathrm{II}^{11}$-, assentando-o em dupla finalidade: educativa e produtiva.

57. Procurando, também nesse passo, reduzir as diferenças entre a vida nas prisões e a vida em liberdade, os textos propostos aplicam ao trabalho, tanto interno como externo, a organização, métodos e precauções relativas à segurança e à higiene, embora não esteja submetida essa forma de atividade à Consolidação das Leis do

\footnotetext{
${ }^{10}$ Art. 28 LEP. O trabalho do condenado, como dever social e condição de dignidade humana, terá finalidade educativa e produtiva. $\S 2^{\circ} \mathrm{O}$ trabalho do preso não está sujeito ao regime da Consolidação das Leis do Trabalho.

${ }^{11}$ Art. 160 CRFB. A ordem econômica e social tem por fim realizar o desenvolvimento nacional e a justiça social, com base nos seguintes princípios: [...] II - valorização do trabalho como condição da dignidade humana.
}

Revista de Direito Brasileira | São Paulo, SP | v. 13 | n. 6 | p. 167 - 189 | jan./abr. 2016 
Trabalho, dada a inexistência de condição fundamental, de que o preso foi despojado pela sentença condenatória: a liberdade para a formação do contrato.(grifo da autora)

Dessa forma, o legislador optou por não conceder os direitos celetistas ao preso em razão da sua falta de liberdade para a formação do contrato. O legislador considerou que a sentença penal condenatória retirou tal liberdade do preso. Todavia, o legislador esqueceu que a própria LEP prevê a necessidade do consentimento expresso do presopara o trabalho prestado externamente em benefício da iniciativa priva, de acordo com o artigo $36, \S 3^{\circ}$, $^{12}$ fazendo suscitar a possibilidade da bilaterialidade exigida pela doutrina trabalhista para $o$ surgimento da relação empregatícia.

Apesar do disposto na LEP e na sua exposição de motivos, em momento anterior à publicação da LEP, havia reivindicações a respeito da possibilidade da concessão dos direitos trabalhistas ao preso, conforme Evaristo de Morais Filho,que em 1975, já dissertava sobre o assunto:

\begin{abstract}
Com o trabalho realizado - quando existente - dentro dos muros das próprias penitenciárias, por conta da administração ou sob seu controle direto, não chega a se configurar um contrato de trabalho entre o apenado e quem lhe exige trabalho. Mas tudo muda de aspecto quando se trata de serviço prestado a terceiros, estranhos à administração, fora do recinto da prisão. Desde que prestado a empresa, pouco importa que o prestador seja um presidiário, no cumprimento da pena - o seu trabalho se equipara ao de qualquer trabalhador livre, com direito a todos os benefícios legais. Não vale invocar incapacidade contratual do apenado, nem alegar possível obrigatoriedade nesta prestação.
\end{abstract}

Nos regimes de semiliberdade e de prisão-albergue, aberta, envolve-se o apenado na vida civil dos cidadãos comuns, com todos os direitos e deveres conferidos a estes. (MORAES FILHO, 1975, p. 214-215)

Destarte, o doutrinador já salientava a divisão em relação a favor de quem o trabalho será prestado. Se for para a administração pública, não há como se configurar o vínculo. Se o beneficiário for uma empresa privada, não será em razão de o trabalhador ser um preso que vinculará a aplicação ou não dos preceitos laborais.

O Projeto de Lei n. 513 de 2013 que pretende alterar a LEP continua a prever a mesma sistemática de marginalização celetista para o trabalho carcerário. ${ }^{13}$ Porém, apesar da justificativa da "falta de liberdade" para contratação exposta na exposição de motivos de 1984 em decorrência da obrigatoriedade do trabalho do apenado, o PL não prevê mais a sua obrigatoriedade, mas sim o incentivo ao labor. ${ }^{14}$ Dessa forma, mesmo sem a obrigatoriedade do trabalho, de acordo com a nova vontade do legislador pátrio disposta no PL,a marginalização persistirá. A incongruência e ilogicidade persistem.

\title{
2.1 ARGUMENTOS PARA O NÃO RECONHECIMENTO DA RELAÇÃo DE EMPREGO
}

Para o não reconhecimento da relação empregatícia é apontado como motivo principal a falta da vontade do apenado para a formação do contrato, visto que é obrigatório. De acordo

\footnotetext{
${ }^{12}$ Art. 36 LEP. O trabalho externo será admissível para os presos em regime fechado somente em serviço ou obras públicas realizadas por órgãos da Administração Direta ou Indireta, ou entidades privadas, desde que tomadas as cautelas contra a fuga e em favor da disciplina. $\S 3^{\circ} \mathrm{A}$ prestação de trabalho à entidade privada depende do consentimento expresso do preso.

${ }^{13}$ Art. 28 PL 513/2013. O trabalho do condenado, como dever social e condição de dignidade humana, terá finalidade educativa e produtiva. [...] $\S 2^{\circ} \mathrm{O}$ trabalho do preso não está sujeito ao regime da Consolidação das Leis do Trabalho, e admite-se o trabalho em função da produtividade.

${ }^{14}$ Art. 31 PL 513/2013. A pessoa privada de liberdade será incentivada ao trabalho na medida de suas aptidões e capacidades. Parágrafo único. É facultativo o trabalho do preso provisório e só poderá ser executado no interior do estabelecimento.
} 
com MIRABETE, 2012, p. 250: "Essa obrigatoriedade do trabalho no presídio decorre da falta do pressuposto liberdade, pois, em caso contrário, poder-se-ia considerar sua prestação como manifestação de um trabalho livre, que conduziria a sua inclusão no ordenamento jurídico trabalhista".

Alice Monteiro de Barros disserta sobre o assunto, justificando que a marginalização celetista pode decorrer da falta da liberdade contratual aliada ao outro elemento, a finalidade do trabalho carcerário (que almeja a ressocialização do apenado, assim como a diminuição da pena):

Exatamente por faltar a liberdade contratual e de escolha do trabalho (consentimento), a legislação brasileira não reconhece o vínculo empregatício com o condenado que presta serviços com a finalidade de reeducação e reinserção na vida social, além de constituir, em determinadas situações, elemento de redução da pena. (BARROS, 2008, p. 405)

E, ao tratar da marginalização trabalhista, assegura: "A exclusão refere-se ao trabalho do preso junto à penitenciária ou a particulares".

Tais autores que defendem a falta da liberdade na pactuação do contrato de trabalho fixam-se no artigo 442 da CLT que estabelece que o "Contrato individual de trabalho é o acordo tácito ou expresso, correspondente à relação de emprego". É nesse ponto que os defensores da marginalização celetista se concentram, pois como não há o "acordo", isto é, a vontade manifestada de forma expressa ou tácita para a formação contratual, não haveria a relação de emprego.

Por sua vez, Vólia Bomfim Cassar justifica a falta do vínculo empregatício da seguinte forma:

Não há vínculo de emprego entre o preso e o Estado, seja porque não aprovado em concurso público (art. 37, II CRFB), seja porque a Lei se manifesta nesse sentido art. 28, § $2^{\circ}$, da Lei 7210/84 (Lei de Execução Penal).

O trabalho do preso tem conotação de reabilitação e exerce forte função social. Mas não é este o motivo que impede a formação do vínculo de emprego, e sim o comando legal que expressamente determina o afastamento da legislação trabalhista (CLT). (CASSAR, 2012, p. 356)

Corroborando a justificativa da autora, também existe a Súmula 363 do TST, ${ }^{15}$ dispondo que o contrato será considerado nulo quando o servidor público não obtiver aprovação em concurso público. Realmente, quando o beneficiário do trabalho for a administração pública, a formação do vínculo é insustentável. Todavia, a doutrinadora esquece que não será apenas a administração pública a beneficiária do trabalho carcerário, mas também a iniciativa privada.

Norberto Avena leciona a respeito do trabalho do preso, conforme abaixo:

O trabalho interno do preso (realizado dentro do estabelecimento penal), sendo uma obrigação cujo descumprimento acarreta a imposição de sanções disciplinares, não está regido pela Consolidação das Leis do Trabalho (art. 28, § $2^{\circ}$, da LEP). O vínculo que se institui, portanto, é de direito público e não um vínculo empregatício. Em consequência, também não existirão encargos sociais incidentes sobre os valores pagos pela utilização dessa mão de obra, a exemplo de aviso prévio indenizado ou não, FGTS, repouso semanal remunerado, férias e décimo terceiro salário.

E quanto ao trabalho externo(realizado fora do presídio)? Tratando-se de preso em regime fechado, não há, do mesmo modo, vínculo empregatício, tampouco

\footnotetext{
${ }^{15}$ Súmula 363 TST. CONTRATO NULO. EFEITOS. A contratação de servidor público, após a CF/1988, sem prévia aprovação em concurso público, encontra óbice no respectivo art. 37 , II e $\S 2^{\circ}$, somente lhe conferindo direito ao pagamento da contraprestação pactuada, em relação ao número de horas trabalhadas, respeitado o valor da hora do salário mínimo, e dos valores referentes aos depósitos do FGTS.
}

Revista de Direito Brasileira | São Paulo, SP | v. 13 | n. 6 | p. 167 - 189 | jan./abr. 2016 
incidência dos referidos direitos sociais. Sendo hipótese de indivíduo que cumpre pena em regime aberto, pacificou-se a jurisprudência no sentido de que "o trabalho externo prestado por condenado em regime aberto não configura o trabalho prisional, previsto na Lei das Execuções Penais", razão pela qual se reconhece "relação de trabalho que se sujeita à tutela da CLT". O tema é discutido, porém, quando se trata de cumprimento de pena no regime semiaberto. Sem embargo da existência de corrente oposta, em inúmeras oportunidades têm os tribunais decidido que "o disposto no $\S 2^{\circ}$ do art. 28 da LEP não pode servir de óbice ao reconhecimento da relação de emprego entre as partes", devendo-se reconhecer a existência de vínculo trabalhista quando se trata de trabalho externo prestado por condenado em regime semiaberto. (AVENA, 2014, p. 48)

Conforme mencionado pelo próprio autor, aos trabalhadores situados no regime fechado não seria possível a configuração do vínculo, pois esses, realmente, não possuem a liberdade de escolha para quem trabalhar. Já no regime semiaberto o tema ainda é discutido. No tocante ao regime aberto, apesar do doutrinador considerar a configuração do vínculo como pacífico nos tribunais, existem muitas decisões não concedendo o liame empregatício. O tema apenas seria totalmente pacífico caso o legislador consagrasse o trabalho prisional do regime aberto e do semiaberto como uma nova categoria de empregados. A celeuma não poderia ficar a cargo única e exclusivamente do poder judiciário. É necessário um debate sério e preciso realizado pela doutrina para a fatídica mudança realizada pelo legislador.

\section{A NECESSIDADE DE UMA NOVA REGULAMENTAÇÃO PARA O TRABALHO PRISIONAL}

A maioria dos presidiários do Brasil apenas possui a sua força de trabalho como instrumento para reinserção social e para a diminuição da sua pena, dessa forma, o trabalho é considerado, para tais pessoas, como um instrumento de valor, porém, o legislador retira o valor que deveria estar agregado ao labor.

Ao marginalizar o preso dos preceitos celetistas não é possível o seu enquadramento em nenhuma outra espécie de trabalhador, seja ele avulso, autônomo, eventual, cooperado, qualquer que seja a modalidade existente no direito trabalhista. Cabe a nós, operadores do direito, reverter tal situação, para que o Estado, enquanto estiver com a custódia do indivíduo, aproveite esse tempo para efetivamente ressocializá-lo.

Na relação de trabalho carcerária o desequilíbrio contratual entre os polos da relação de trabalho é ainda mais contundente. Isso ocorre em razão da ausência do ente que deveria protegê-los coletivamente perante os abusos patronais, que seriam os sindicatos (ou inclusive outras organizações superiores, como as federações e confederações). As organizações sindicais não existem, pois aos presos não é conferida a possibilidade de associação sindical. Assim, resta apenas cada trabalhador individualmente isolado, desprotegido perante as regras mal formuladas que não são discutidas e debatidas desde a sua origem. Dessa maneira, a disparidade existente entre os contratantes é muito maior do que numa relação de emprego reconhecida formalmente. Assim, a proteção típica do direito trabalhista deveria, de uma forma ainda mais forte, abrigar tais trabalhadores, porém, é exatamente o contrário: mais mais fraca a parte contratual, maior é a sua desproteção.

Isabella Monteiro Gomes defende a situação de afronta aos ditames constitucionais:

\footnotetext{
Negar ao preso o reconhecimento da relação de emprego, o reconhecimento pleno do contrato de trabalho, não se compatibiliza com os mandamentos constitucionais de proteção ao trabalho. No caso do sujeito inserido no sistema carcerário, a diretriz deveria ser mais incisiva quanto à total integração do preso no mercado de trabalho, não apenas no aspecto da qualificação, treinamento, desenvolvimento da atividade laborativa, mas também, no aspecto do reconhecimento de direitos. Além de ser situação discriminatória, o que também é inconcebível pela ordem constitucional. (GOMES, 2011)
}

Revista de Direito Brasileira | São Paulo, SP | v. 13 | n. 6 | p. 167 - 189 | jan./abr. 2016 
Novamente, cita-se Amaro Barreto, que, desde 1943, já pregava um tratamento igualitário para o trabalho carcerário:

Nos regimes carcerários predominam as considerações de ordem jurídico-social que tendem a transformar o penado de hoje no homem útil de amanhã, o que aconselha a aproximar ao máximo o trabalho carcerário daquele que é livre, não só em natureza, senão ainda em direitos e obrigações [...].(BARRETO, 1943. p. 354)

No mesmo sentido, Epaminondas de Carvalho:

Cumpre-nos reconhecer e confessar, sem rodeios, que os futuros regulamentos carcerários, atendendo ao fenômeno de humanização e democratização do direito, terão de plasmar ainda mais a tendência, igualando o trabalho carcerário ao livre, mesmo porque, em hipótese alguma poderão autorizar medidas que exponham a perigo a saúde ou ofendam a dignidade da pessoa humana. (CARVALHO, 1944, p. 190)

Todavia não é possível uniformizar o preso e o trabalhador livre em igualdade de condições, pois o cerceamento da liberdade do preso (por mais que não lhe retire o direito à relação de emprego) dificulta a aplicação de diversos direitos trabalhistas dentro do cárcere. Um exemplo é o direito à jornada extraordinária: o preso que trabalha externamente possui um rígido controle de saída e entrada no estabelecimento prisional que deverá ser seguido à risca. Dessa forma, mesmo que surgissem necessidades imperiosas em seu trabalho, não seria permitida a sua permanência na empresa, pois deverá ser recolhido à prisão no horário marcado.

No mesmo sentido, Vanessa Barbosa Trama afirma que:

[...] a legislação deveria ser revista com o objetivo de adequá-la à situação fática do condenado, não com o intuito de igualar o vínculo empregatício do encarcerado ao do cidadão livre, mas sim garantir o mínimo de proteção possível e viabilizar que o ofício desempenhado possa servir de incentivo quando o apenado tiver sua liberdade restabelecida.(TRAMA, 2010. p. 252-253)

Ou seja, o trabalho em condições de quase equiparação com o trabalhador livre seria uma forma de instigar o trabalhador para demonstrar como é regulado o direito trabalhista na realidade. É necessário demonstrar para o preso como funciona a vida em sociedade com carteira assinada, sendo justamente esse o desejo da ressocialização: preparar o preso para o futuro retorno ao convívio com os demais.

Olga Espinoza relata boa parte dos atuais problemas enfrentados no trabalho no cárcere atualmente:

Não obstante o trabalho em geral seja valorizado pelas pessoas presas e considerado atividade benéfica, a realidade é muito mais complexa para aqueles que desejam trabalhar, pois a administração penitenciária não proporciona postos suficientes para cobrir a demanda nas prisões [...]. Se a isso somarmos a legitimação da discriminação que se concretiza por meio da Lei de Execução Penal quando restringe ao preso a possibilidade de fazer uso das leis que protegem os trabalhadores, o panorama que se descortina é o que julga as mulheres e homens presos desprovidos da capacidade de exercer seus direitos sociais e de sentir em iguais condições ao cidadão livre. Paradoxalmente, a mesma legislação que pretende destacar as diferenças entre o cárcere e o mundo exterior proclama a integração social pós-prisão. Tais antinomias reforçam os postulados foucaultianos de que a prisão não responde às funções declaradas nos preceitos legais, uma vez que tem como finalidade delimitar as fronteiras entre as ilegalidades e a delinquência, estigmatizando aqueles que se encaixam no segundo grupo. (ESPINOZA, 2004, p. 137)

O trabalho do apenado é marginalizado do direito trabalhista. Porém, o direito trabalhista, seja ele o celetista ou não, é indispensável para regular a proteção cabível para o homem enquanto trabalhador. Porque não dignificá-lo como um ser que efetivamente está necessitado de proteção, abrangendo-o como uma nova categoria de trabalhadores, como é o aprendiz? O aprendiz também é uma pessoa que, como o próprio nome já menciona, está

Revista de Direito Brasileira | São Paulo, SP | v. 13 | n. 6 | p. 167 - 189 | jan./abr. 2016 
aprendendo, está em uma fase de integração social, de aprendizado, vinculado com o início da vida, desenvolvendo as suas atividades de maneira compatível com o seu desenvolvimento físico, moral e psicológico, conforme menciona o artigo 428 da CLT. A aprendizagem encontra muita similitude com o trabalho do apenado, porém, nem em função disso, o aprendiz é marginalizado do direito trabalhista. Por exemplo, há pagamento do FGTS, mas a sua alíquota é de $2 \%$, em vez da alíquota de $8 \%$ para os demais trabalhadores. Tal raciocínio pode e deve ser aplicado ao apenado.

O encarcerado deverá possuir o direito a uma Carteira de Trabalho e Previdência Social assinada, com direitos trabalhistas garantidos, nem que sejam em escala menor, mas que os tenha, e além do mais, ao término do cumprimento de sua pena poderá exibir para o novo empregador a sua CTPS assinada com as anotações pertinentes. Inclusive, a própria empresa que o contratou poderá continuar com o pacto após o cumprimento da pena. Sairá ganhando o empregado assim como o empregador, que possuirá um empregado pronto e já qualificado para as atividades a serem desempenhadas.

Além do mais, durante todo o treinamento do apenado na penitenciária poderá ser pago apenas um salário-mínimo, e para as demais filiais da mesma empresa o piso salarial poderá ser mais elevado, sendo vedada a equiparação salarial nesses casos, surgindo uma nova espécie de direito trabalhista aplicado aos empregados no cárcere, assim como existe entre os trabalhadores urbanos, rurais e domésticos. E, para que não ocorra a concorrência desleal no setor, deverá ser estipulado o número máximo de empregados apenados, proporcionalmente ao número de trabalhadores livres contratados pela mesma empresa. Assim o empregador que utiliza a mão de obra prisional não teria grandes desonerações financeiras a ponto de ferir a livre concorrência.

Agora, suponha-se a situação de um condenado a oito anos ao regime semiaberto. Imagine-seque o mesmo preso resolva trabalhar logo no início do cumprimento de sua pena e assim se mantenha até a sua soltura para a vida em liberdade, quanto tempo essa pessoa irá trabalhar sem direito ao descanso anual, ou seja, as férias? Sem dúvidas, ao término da pena, a pessoa estará com alguma fadiga física, pois o corpo precisa de certo tempo estendido para repor suas energias. Epaminondas de Carvalho defende o mesmo ponto de vista em relação às férias, mas aplicado ao trabalho prisional:

É fácil ver que o direito ao gozo de férias remuneradas constitui uma das mais importantes conquistas do trabalhador. Qual a razão de ordem jurídica ou moral invocada para a denegação do benefício ao penitenciário que trabalha durante um ano, dispensando considerável soma de energias?

Qualquer justificação, além de anti-humana, não poderá ser enquadrada na nova concepção do direito, já que não vivemos mais estribados no falso postulado da igualdade teórica.

A cessação do trabalho, com o fim de repouso, é uma necessidade que se não pode negar a pessoa humana, já porque tal direito tem uma tendência universalista, já ainda porque, a repetição de atos de atividade, leva fatalmente ao esgotamento de energias, à fadiga, causa psicológica dos acidentes.

Qualquer que seja a espécie de atividade humana, o trabalho não deve ser executado em estado de fadiga.

Sob este perfil, a sociedade exige que o penitente ao ser devolvido ao seu meio, conserve uma capacidade de trabalho revigorada, visando, assim, [sic] um melhor rendimento.

Pouco importa que o descanso seja feito no próprio estabelecimento penal, de forma intercalada ou prolongada. Pouco importa, ainda, que não possa o recluso afastar-se temporariamente do ambiente em que trabalha e vive, muito embora, possa ser transferido para outro presídio de igual regime.

Cremos que, nos tempos modernos, é necessário que o trabalhador descanse para que não execute trabalhos em estado de esgotamento. $\mathrm{O}$ repouso, portanto, como lei 
biológica que é, não pode ser negado ao penado, pois seria negar a própria dignidade da pessoa humana.(CARVALHO, 1944. p. 190-191)

É evidente, até mesmo para um leigo, que o trabalho realizado ano após ano sem o período de descanso detém uma possibilidade maior de causar acidentes. O Estado, ao possuir a custódia do indivíduo, deveria guiar o trabalho de forma que a integridade física e psíquica do apenado não seja abalada. Assim, deveriam ser concedidas as férias anuais para os apenados trabalhadores.

O preso precisa aprender, precisa ser educado de que, após tanto tempo de trabalho, há o repouso anual remunerado. Não precisaria ser o descanso anual típico celetista de 30 dias, mas, no caso, um descanso de 10 dias, inclusive para o apenado entender como funciona a sistemática trabalhista (período aquisitivo de férias, para depois ocorrer o período concessivo), configurando uma típica interrupção do contrato de trabalho, inclusive para os cálculos de remição da pena. Entende-se que o período de férias pode ser reduzido, pois as férias possuem diversas finalidades, para descansar, para viajar, para o lazer, mais tempo com a família, entre inúmeros benefícios. Como o preso encontra-se com a sua liberdade de ir e vir cerceada, muitos desses benefícios não são adimplidos, e assim o número de dias de férias poderá ser reduzido.

Se o contrário for demonstrado para ele, isto é, que apenas há trabalho sem o descanso anual, o trabalho do apenado poderá fazer o caminho contrário ao da ressocialização: além de lesionar fisicamente e psicologicamente a pessoa, poderá transformá-lo em um "revoltado contra o sistema", mais do que, porventura, ele já possa ser.

O preso, assim como qualquer ser humano, é detentor de dignidade, Ingo Wolfgang Sarlet em seu livro dedicado ao assunto disserta quanto ao conceito do princípio:

\begin{abstract}
A qualidade intrínseca e distintiva de cada ser humano que o faz merecedor do mesmo respeito e consideração por parte do Estado e da comunidade, implicando, neste sentido, um complexo de direitos e deveres fundamentais que assegurem a pessoa tanto contra todo e qualquer ato de cunho degradante e desumano, como venham a lhe garantir as condições existenciais mínimas para uma vida saudável, além de propiciar e promover sua participação ativa e co-responsável[sic] nos destinos da própria existência e da vida em comunhão com os demais seres humanos. (SARLET, 2007, p. 62)
\end{abstract}

Ademais, o autor ainda aborda a aplicação do princípio:

\begin{abstract}
Além disso, como já frisado, não se deverá olvidar que a dignidade - ao menos de acordo com o que parece ser a opinião largamente majoritária - independe das circunstâncias concretas, já que inerente a toda pessoa humana, visto que em princípio, todos - mesmo o maior dos criminosos - são iguais em dignidade, no sentido de serem reconhecidos como pessoas - ainda que não se portem de forma igualmente digna nas suas relações com seus semelhantes, inclusive consigo mesmos. (SARLET, 2007, p. 45)
\end{abstract}

Assim sendo, de acordo com o autor, a dignidade seria um atributo inerente ao complexo de direitos e deveres fundamentais, garantindo as condições de existência mínimas dos seres humanos. Além disso, não haveria motivos para retirar a aplicação do princípio aos apenados, sendo esse, justamente, o exemplo trazido pelo jurista.

Como no Brasil a situação trabalhista do preso não é encarada como uma relação especial, resta a vinculação na forma celetista, pois é a vala comum aplicada para os trabalhadores, sendo a solução existente no ordenamento jurídico brasileiro. Porém, deveria ser realizada uma legislação trabalhista específica para o preso, pois existe uma série de situações que não permite a equiparação total aos trabalhadores livres (a esse respeito, cita-se logo acima o exemplo das férias e da jornada extraordinária). Enquanto não for realizada a lei prevendo a relação especial, resta aplicar-se a relação de emprego tipicamente celetista.

Revista de Direito Brasileira | São Paulo, SP | v. 13 | n. 6 | p. 167 - 189 | jan./abr. 2016 
Nessa senda, uma situação que não poderá deixar de ser retratada é o fato de um dos argumentos contra a vinculação via contrato de trabalho do apenado ser que a mão de obra prisional igualmente considerada como a dos trabalhadores livres tornaria a laborterapia um negócio sem atratividade, pois o empregador preferiria contratar trabalhadores livres, dado o fato da vida pregressa do apenado não ser recomendável.

Porém com o "barateamento" da mão de obra prisional acaba por acontecer o dumping social ferindo o direito à livre concorrência entre as empresas que seguem à risca o pagamento dos direitos trabalhistas conforme citado acima, podendo resultar no desemprego de trabalhadores livres, pois se tornam mais "caros". Além disso, independentemente do ocasionamento de demais problemas sociais, o trabalho do preso não poderá ser considerado uma "mercadoria" a ser comercializada com a barganha entre trabalhadores livres e presos.

Se não fosse esse o único problema (os direitos da relação de emprego restringidos), não há garantia aos presos de que eles serão empregados da empresa que se utilizou de sua mão de obra durante o cárcere após o cumprimento da pena. O Estado, ao disponibilizar a mão de obra apenada, geralmente, não faz nenhum incentivo para que a contratação perdure na vida em liberdade.

Rui Carlos Machado Alvim assevera a respeito da falta de proteção aos trabalhadores encarcerados:

Justamente àquelas pessoas diretamente custodiadas pelo Estado, desrespeita-selhes, por inaplicabilidade, o estatuto protetivo de todos os trabalhadores. Ou seja, o Estado, ao reverso de dar cumprimento ao direito posto, passa a acobertar práticas ilegais e ilegítimas.

Será que a mens legis ou a mens legislatoris dá curso, implicitamente, ao repisado argumento - mais falado e percebido que escrito - de que o desafogo dos encargos sociais se constituiria em irrecusável incentivo às empresas privadas nas contratações do pessoal presidiário, à medida que o trabalho presidiário se notabiliza por uma irrequieta indisciplina, qualidade precária, desinteresse e produção lenta? Tais desmazelos, se reais, talvez provenham menos do fato de o trabalhador ser presentemente preso e preteritamente afastado do mercado de trabalho, do que efeito, e protestos, por um pagamento injusto [...].(ALVIM, 1991, p 40)

Rui Carlos Machado Alvim critica o fato de que os direitos trabalhistas, que são imperativos estatais, são descumpridos àqueles que estão sob a custódia estatal. O próprio Estado, que deveria assegurar a aplicação do direito posto, acoberta práticas ilegítimas.De acordo com o autor, os argumentos utilizados para desafogar os encargos trabalhistas não são plausíveis de aplicação.

Paula Julieta Jorge de Oliveira observa a mesma situação, mas diante da responsabilidade social da empresa:

Não é possível admitir que a utilização da mão-de-obra [sic] prisional vise exclusivamente aos benefícios econômicos da empresa, mas deve atender aos ditames de responsabilidade social e participação no processo de desenvolvimento da cidadania e resgate da dignidade do apenado. Por essa razão, as empresas que se dispuserem a investir na recuperação desses indivíduos devem contabilizar suas ações em seu Balanço Social, e não beneficiarem-se de eventuais desonerações para melhor posicionarem-se no mercado em relação às demais empresas do ramo.

É impossível reconhecer iniciativas de responsabilidade social quando uma empresa emprega exclusivamente mão-de-obra [sic] prisional, a fim de minimizar seus custos e assim burlar as regras de competitividade do mercado; é ainda mais inadmissível a conivência do Poder Público que justifica essas ações como necessárias, pois se assim não o fosse não existiriam vagas para o trabalho dos sentenciados. (OLIVEIRA, 2010)

Consoante à autora, se valer do expediente como a falta de oportunidades para os presos (caso os direitos trabalhista sejam conferidos a tais pessoas) é se utilizar de artifícios maldosos para ferir a livre concorrência e a própria responsabilidade social da empresa. Se a 
empresa efetivamente desejasse a responsabilidade social, deveria colocar essas ações em seu balanço social e não se aproveitar de desonerações trabalhistas a fim de reduzir seus custos. Além disso, a autora ainda critica a conivência da administração pública que justifica esse expediente.

Acerca do assunto, Jorge Luiz Souto Maior explica a ausência da procura empresarial caso fossem concedidos direitos trabalhistas aos presos:

Poder-se-á argumentar que sem um incentivo, representado pela redução do custo da mão-de-obra [sic], as empresas sairão dos presídios, deixando sem alternativa os presidiários. No entanto, é preciso verificar que fora dos presídios há uma gama enorme de trabalhadores desempregados que não se engajaram, ainda, no crime, e que estão sendo privados de ocupação, pois as empresas arrumaram uma fórmula de exploração do trabalho ainda mais lucrativa dentro dos presídios.

Além disso, a reabilitação dos presos é um dever do Estado e não pode este se eximir de seu dever pura e simplesmente retirando dos presidiários parcela de seus direitos trabalhistas, numa espécie de barganha.

A promiscuidade entre o público e o privado que há por detrás dessa exploração, ademais, é bastante denunciadora da irregularidade da situação criada. Talvez por isto que a construção de presídios para a formação de um autêntico exército de mãode-obra [sic] barata esteja se constituindo um negócio altamente lucrativo para muitas pessoas, movimentado, aliás, pela lógica de uma bola de neve, pois quanto mais há exploração nos presídios, mais há pessoas desempregadas fora dos presídios, que, diante da necessidade, acabarão, cedo ou tarde, tornando-se, igualmente, habitantes da carceragem. E se a moda pega, daqui a pouco vai ter gente pedindo para ser preso, ou pior, cometendo assumidamente um crime, só para poder arrumar trabalho, mesmo sem a garantia de todos os seus direitos. (MAIOR, 2008, p. 66-67)

O doutrinador mostra o círculo vicioso, a maldosa lógica do sistema trabalhista/capitalista carcerário que atinge pessoas que não estão com a sua liberdade cerceada, mas que indiretamente sofrem os efeitos do "barateamento" do serviço carcerário. No momento em que existe uma brecha em que os valores gastos com a produção sejam mais acessíveis aos empresários, será nesse nicho que eles irão se concentrar. É exatamente por isso que os direitos trabalhistas não poderão ser renunciados pelas partes, para não surgirem trabalhadores mais desvalorizados economicamente e consequentemente não haver a sua superexploração.

O fim do direito do trabalho é justamente evitar que condutas como a que a massa carcerária trabalhadora sofre continuem a existir.A argumentação da falta de incentivos aos empresários é nefasta à sociedade, não podendo ser invocada, pois fere os princípios constitucionais, assim como toda a caminhada alcançada pelo direito do trabalho, além dos demais argumentos já aqui assinalados.

Para que não ocorra essa barganha de direitos trabalhistas, é necessária uma ponderação de interesses presentes no trabalho penitenciário, e a respeito disso Gláucio Araújo de Oliveira apresenta que:

O tema ora abordado não pode ser desprezado ou posto em segundo plano, seja conferindo parcos direitos sociais ao recluso, alimentando a voracidade da indústria de exploração de mão de obra carcerária com vistas a atender exclusivamente os anseios econômicos da iniciativa privada, ou visando suprir carência de pessoal da administração pública. Da mesma forma, a complexidade do tema não permite que se autorize de forma irresponsável toda a gama de direitos trabalhistas contemplados pelo regime geral de trabalho livre. O tema é tormentoso, merece análise profunda de cada sistema penitenciário, do seu correspondente ordenamento legal, a realidade socioeconômica, entre outros elementos relevantes. Deve-se ponderar sobre quais garantias, direitos, deveres e outras obrigações devem ser conferidos ao trabalhador preso. Certamente que o trabalho penitenciário deve ser visto sob outra ótica, mais próxima de uma conduta voltada para a responsabilidade social por parte dos beneficiários dessa mão de obra diferenciada e mais distante de interesses 
econômicos voltados exclusivamente para a redução de custos produtivos.(OLIVEIRA, 2010, p. 166-167)

Rui Carlos Machado Alvim na sua incessante defesa ao trabalho carcerário assevera: A efetivação dos direitos sociais ao preso trabalhador, enquanto lhe humaniza o trabalho e suas condições, resulta na humanização consciente do próprio preso, contribuindo, concomitantemente, para seu reingresso na dignidade humana, esvaída em sua condição carcerária, e para a superação de sua alienação, tanto a proveniente de sua solitária rebeldia quanto a do próprio trabalho desprotegido. (ALVIM, 1991, p. 94)

As sanções penais evoluíram muito ao longo de toda a história humana, já passando por momentos de penas de mutilação, penas de morte e de caráter aflitivo. A atualidade da pena privativa de liberdade demonstra a evolução do pensamento de que a pena não precisa ser encarada como algo doloroso para o condenado. Seguindo os passos de tal evolução, conferir os direitos trabalhistas para os apenados seria uma nova caminhada almejando a contemplação da dignidade da pessoa humana aplicada ao preso. Nesse mesmo sentido, trazse o entendimento de Jorge Luis Souto Maior:

[...] há de se ponderar que quando esse trabalho é aproveitado no contexto de uma exploração econômica ou mesmo para a satisfação de algum interesse do próprio Estado (econômico ou não), tem-se a inevitável formação da relação de emprego, da qual decorrem todos os direitos que lhe possam, pelas características próprias, ser aplicáveis, pois o fato de estar cumprindo pena não diminui o alcance da cidadania do preso.[...] O que se percebe é que o legislador penal não conseguiu equacionar as razões de ordem pública que se inserem na questão: de um lado, a proteção social do trabalhador, como fator da dignidade da pessoa humana; e de outro, a necessidade de apenar os atos que constituem ilícito penal, assim como não conseguiu se desapegar dos preconceitos socioculturais pelos quais se encara o trabalho manual. (MAIOR, 2008, p. 65)

Conforme destacado, o atual legislador brasileiro, diante da laborterapia, não conseguiu ponderar o fato do apenado como um ser merecedor de dignidade em seu trabalho, conjuntamente com a questão da punição a ser aplicada a um desviante. Se essa ponderação ainda não foi criada, já está mais do que em tempo de ser idealizada. A pena no atual ordenamento brasileiro possui caráter transitório, o tempo máximo que o apenado poderá ficar detido são trinta anos, conforme artigo 75 do CP. O Brasil veda a pena de morte e a pena perpétua, dessa forma, o apenado, em um curto ou longo período de tempo, já estará no seio da sociedade novamente. Para que isso ocorra sadiamente, o apenado deverá ser ressocializado, tornando-se apto para viver pacificamente sem a ânsia de cometer novos delitos, com a expectativa de que ele não se torne um reincidente.

Para se sair desse círculo vicioso em que se encontra a sociedade, o trabalho faz parte de alternativa para a reinclusão social.Mas, para isso, o trabalho deverá ser muito bem executado. Conforme destacado por José Nabuco Galvão de Barros Filho:

Enquanto a sociedade não se preocupar em construir um sistema penal que propicie
a reinserção social do preso, os alarmantes índices de criminalidade continuarão a
crescer. Enfim, é preciso se conscientizar de que a segurança pública também
depende do respeito aos direitos do detido. (BARROS FILHO, 1997, p. 173.)

Ou seja, diante da sentença transitada em julgado, diante do crime configurado e a autoria reconhecida, a sociedade e os poderes públicos precisam reagir para que o já ocorrido não aconteça novamente. E, para isso, conscientização e políticas devem ser corretamente efetuadas.

A inclinação deste estudo é para a concessão de um contrato de trabalho especial, com a configuração da relação de emprego com a iniciativa privada para os apenados do regime aberto, assim como para os do semiaberto laborando externamente em benefício da iniciativa privada, visto que é dada a opção do trabalho a ser realizado. Esse seria um primeiro passo. 
Após a implementação, poderia, num futuro, ser estendido tal direito para os apenados em regime fechado. Porém, como ainda não foi construída essa modelação especial do regime de trabalho carcerário, utilizar-se-ia a CLT aplicável à laborterapia.

Uma certeza há: a situação do trabalho prisional não poderá continuar a ser enfrentada conforme o modo hoje escolhido pelo Brasil. No atual momento em que o direito trabalhista, constitucional, assim como os direitos humanos, além de outros ramos que cuidam da pessoa, se encontram, é inconcebível que situações como a do apenado sejam regulamentadas da forma como o são agora. É inadmissível que a conjuntura construída ao longo de tantos anos de lutas de classes seja excluída de uma parcela de trabalhadores.

A jurisprudência já vem caminhando no sentido de reconhecer o vínculo do apenado conforme os moldes celetistas, conforme verificado abaixo:

RELAÇÃO DE EMPREGO. TRABALHO PRISIONAL. Não se configura o trabalho prisional, previsto na Lei das Execuções Penais,quando se trata de trabalho externo, prestado por condenado em regime semi-aberto [sic]. Relação que se admite estabelecida sob os moldes empregatícios, sujeita à tutela da CLT. ${ }^{16}$

VÍNCULO DE EMPREGO. PRESIDIÁRIO. No direito e no sistema penal brasileiro, a execução da pena, segundo a natureza e a gravidade do crime, e, ainda, segundo o grau de periculosidade do apenado, pode se dar em "regime fechado", "regime semi-aberto [sic]" e em "regime aberto" (por condenação mesma ou por progressão de regime), consistindo direito do preso nestes dois últimos, devidamente autorizado e atendidas às limitações de conduta decorrentes da sua condição, o acesso ao trabalho em condições normais com os demais trabalhadores urbanos. ${ }^{17}$

Nestes acordãos os desembargadores admitem a configuração da relação de emprego aos apenados do regime aberto e semiaberto, pois encontra-se desconfigurada o trabalho típico previsto na LEP.

\section{CONSIDERAÇÕES FINAIS}

São louváveis os preceitos dispostos ao longo da Lei de Execução Penal brasileira, porém, eles estão distanciados e separados por um grande abismo da atualidade nacional, o que tem transformado a LEP, em muitos aspectos, em letra morta pela falta de estrutura e conjuntura do ali disposto.No atual contexto prisional brasileiro uma nova política prisional tem sido pensada. É sabido que muitos condenados saem da prisão de uma forma muito pior do que entraram, que as condições carcerárias do Brasil estão longe das ideais. Pode e deve ser pensada, dentro dessa nova política, a questão do trabalho prisional, justamente com o fim de reabilitação do condenado para a futura vida em sociedade.

Se o trabalho dentro do sistema capitalista em que se vive atualmente possui tanta relevância, este, portanto, deverá ser tratado com adequada importância, inclusive, e ainda com maior vulto para as pessoas que mais precisam desse incentivo.Para isso, o trabalho, apontado, unanimemente, pela doutrina como fator de ressocialização do preso, deverá trilhar ações concretas ou ações bem encaminhadas e projetadas, e sair do discurso ideológico doutrinário. Para que isso ocorra, primeiramente é necessário o reconhecimento do tratamento diferenciado a respeito do trabalho diante de cada regime e de cada beneficiário do trabalho. Feito isso, regulamentações específicas visando ao tratamento do preso deverão ser realizadas, contemplando as finalidades almejadas por cada situação. Não é admissível que uma relação

\footnotetext{
${ }^{16}$ RIO GRANDE DO SUL. Tribunal Regional do Trabalho da $4^{\mathrm{a}}$ Região. $1^{\mathrm{a}}$ Turma. Processo n. 007490003.2006.5.04.0811 RO. Relatora Des. a Ana Luiza HeineckKruse. 27 de agosto de 2009. Disponível em: <www.trt4.jus.br>. Acesso em: 1 jul. 2013.

${ }^{17}$ RIO GRANDE DO SUL. Tribunal Regional do Trabalho da $4^{\text {a }}$ Região. $4^{\text {a }}$ Turma. Processo n. 01738-2002403-04-00-4 DIV-VT. Relator: Milton Varela Dutra. 13 de dnovembro de 2003. Disponível em: <www.trt4.jus.br>. Acesso em: 1 jul. 2013.
}

Revista de Direito Brasileira | São Paulo, SP | v. 13 | n. 6 | p. 167 - 189 | jan./abr. 2016 
de trabalho realizada entre particulares seja tratada perante o Estado como uma relação de índole administrativa, unicamente pelo fato do apenado encontrar-se sob a custódia do Estado. Pensamentos como esse viciam todo o sistema do trabalho prisional, equipando relações realizadas entre particulares (que deveriam ser tratadas em consonância com o direito privado) como situações de direito público.

Não se tentou adentrar na questão de se as penas cabíveis no Brasil são justas ou não, se a prisão efetivamente é a melhor alternativa para os desviados da sociedade. Estas, sim, são questões que são exclusivas para o direito penal. O que se tentou abordar é o ponto de choque entre o direito penal e o direito do trabalho. Abordou-se a consequência do desvio da vida em sociedade, quando a pena já estiver na sua execução e a incidência do labor nessa punição restritiva à liberdade.

Apesar de todos serem considerados iguais perante a lei, o apenado possui sérios cerceamentos que não permitem uma equiparação, uma equivalência de condições com os cidadãos.No entanto, não é porque inexiste a citada igualdade que deverá ser menosprezada a dignidade, afinal, a falta de um princípio não anula o outro, e mesmo o trabalhador estando adstrito da sua liberdade de ir e vir os demais direitos que não guardam relação direta com a liberdade de locomoção poderão se manter conservados.

Todavia, merece atenção o fato de que não se defende aqui a aplicação na integralidade dos direitos trabalhistas ao apenado, mas parte deles, que poderão ser flexibilizados, como é o caso do descanso anual remunerado, que é necessário não apenas para o lazer, mas principalmente para evitar a lesão e fadiga do ser humano.Assim, sustenta-se que ao preso poderá ser criada uma legislação especial, justamente em função do seu caráter situacional peculiar. Porém, como na atualidade brasileira não existe nenhuma relação especial que guarde relação com o trabalho prisional, cabe autilização comum aplicável a (quase) todos os empregados, a CLT.

O direito do trabalho possui uma razão em existir, e a sua finalidade é, principalmente, a proteção dos trabalhadores. O preso também é um trabalhador e, consequentemente, merece atenção legislativa com os cuidados atinentes à pessoa humana na execução laboral. Políticas, planos, projetos devem ser muito bem aplicados, pois no momento em que o trabalho surge como uma alternativa de reinserção social, os cuidados devem ser redobrados. Atualmente, o trabalho, diversas vezes, acaba por ter um fim de uma sanção ainda maior, como se a pena privativa de liberdade já não fosse suficiente por si só e, por fim, não caracteriza a almejada ressocialização.

É possível a configuração do liame empregatício no momento em que um particular se utiliza da força de trabalho de outrem com o objetivo de lucro. E mesmo não sendo possível a configuração da relação empregatícia em razão da falta de algum elemento essencial, alguns direitos deverão ser conferidos, pois fazem parte da dignidade da pessoa humana.

A doutrina penalista desconhece os preceitos fundamentais do direito trabalhista e acaba se equivocando na abordagem dos temas. Por sua vez, a doutrina laboral acaba por não adentrar no mérito da questão, visto que a LEP marginaliza o trabalho do apenado da CLT e,assim, os trabalhistas enganam-se, deixando a problemática para o direito penal. Se a Lei e os operadores do direito continuarem a prever a marginalização celetista aos apenados,isso poderá ocasionar o caminho contrário ao desejado. O preso não verá o trabalho com o intuito de crescimento pessoal, como uma relação recíproca de direitos e deveres, encarando-se cada vez mais abusado e inferiorizado pelo Estado e pela sociedade, apenas sendo utilizada sua mão de obra com o objetivo de produtividade e lucro.O seu labor não possui o mesmo valor que o realizado fora da prisão, simplesmente pelo fato de encontrar-se preso, porém a sua condição de preso, em regra, não deveria intervir na sua condição de trabalhador.

Não se pode continuar penalizando a pessoa que cometeu um crime, por mais grave que esse delito seja, privando-o de direitos que podem ser estendidos a ele mesmo durante o 
cumprimento de sua pena. $\mathrm{O}$ Estado, ao proibir a pena de morte e a pena em caráter perpétuo, deverá preparar o futuro egresso para que tenha condições de viver com os demais.

Cai-se na premissa de como ressocializar o preso, sendo que essa pessoa talvez nunca possa ter sido socializada. Muitas vezes é afirmado que os presos saem da prisão de uma forma pior do que entraram, esta é chamada de "a escola do crime".O trabalho devidamente regulado poderá mudar, e muito, a situação.O apenado deverá ser reeducado, ou em casos mais graves, educado, visto que a educação pode nunca ter sido passada a ele, recebendo pela primeira vez os ditames de uma vida regrada, com uma política social, com direitos e deveres. Isso deverá ser ensinado, passado e repassado ao apenado, e, com o advento da sua liberdade, este poderá ser um cidadão efetivamente apto para colaborar com a sociedade da qual foi retirado.

À parte dessa discussão, insta frisar que uma questão que dificulta a abordagem do tema no Brasil é o fato de o direito penitenciário ser tratado como um ramo dentro do direito penal, pois a sua contribuição acadêmica ainda é pequena. O direito penitenciário deverá ser considerado isoladamente, visto que possui princípios, estrutura, pensamentos peculiares à execução da pena. Com certeza, o ramo em comento possui certo crescimento doutrinário, mas precisa muito mais, é necessário um status com autonomia para a devida discussão e importância que o segmento merece, e nessa pauta entraria a questão do trabalho carcerário.

É uma utopia imaginar que o trabalho do preso desmarginalizado dos preceitos trabalhistas será pacífico e unânime na sociedade, longe das críticas. Sempre haverá vozes contra os cuidados a tal parcela da população que está segregada da vida civil em razão de ter cometido um crime. Não se procura aqui pacificar o tema, longe disso, procura-se exatamente criar direitos que visem à proteção, calcando o embasamento para tanto no princípio da dignidade da pessoa humana, visto que o preso, apesar de recluso, continua sendo uma pessoa humana, apesar de, atualmente, ser tratado como se não fosse uma. Consequentemente, as polêmicas nascerão junto a tais direitos.

Por fim, a contínua desvalorização do trabalho carcerário continua a fomentar a descrença no sistema prisional brasileiro, que deveria servir de reabilitação, mas está por realizar o inverso, com a falta de observância aos preceitos trabalhistas. Punir o condenado não basta. São necessárias providências além da punição para que esse indivíduo tenha uma verdadeira reintegração pós-cárcere.

\section{REFERÊNCIAS}

ALVIM, Rui Carlos Machado. O trabalho penitenciário e os direitos sociais. São Paulo: Atlas, 1991.

ASCOM/MPT-PR. Paraná tem presos trabalhando por salário de R \$ 30,00, afirma MPT-PR.

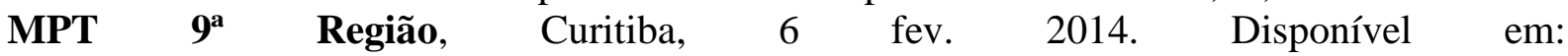
$<$ http://www.prt9.mpt.gov.br/procuradorias/45-noticias-prt-curitiba/424-parana-tem-presostrabalhando-por-salario-de-r-30-afirma-mpt-pr-2>. Acesso em: 7 abr. 2014.

AVENA, Norberto. Execução penal: esquematizado. São Paulo: Método, 2014.

BARRETO, Amaro. O trabalho penal em face do novo Direito. Revista do Trabalho, Rio de Janeiro, v. 11, n. 6, p. 353-354, 1943.

BARROS, Alice Monteiro de. Contratos e regulamentações especiais de trabalho: peculiaridades, aspectos controvertidos e tendências. 3. ed. São Paulo: LTr, 2008. 
BARROS FILHO, José Nabuco Galvão de. O direito de informação e o direito dos presos. Revista de Informação Legislativa, Brasília, n. 135, p. 169-173, 1997.

BRASIL. Tribunal Superior do Trabalho. Disponível em: <http://www.tst.jus.br/>.

CARVALHO, Epaminondas de. Tem o penitenciário direito ao gozo de férias anuais? Revista do Trabalho, Rio de Janeiro, v. 12, n. 4, p. 189-191, 1944.

CARVALHO, Salo de. Antimanual de criminologia. 2. ed. Rio de Janeiro: Lumen Juris, 2008.

CASSAR, Vólia Bomfim. Direito do trabalho. 6. ed. Niterói: Impetus, 2012.

CHIES, Luiz Antônio Bogo. Privatização penitenciária e trabalho do preso. Pelotas: Educat, 2000.

ESPINOZA, Olga. A mulher encarcerada em face do poder punitivo. São Paulo: IBCCRIM, 2004.

FERNANDES, Fátima. Indústria disputa trabalho barato do preso. Folha de São Paulo, São Paulo, 19 fev. $2006 . \quad$ Disponível em: <http://www1.folha.uol.com.br/folha/dinheiro/ult91u105377.shtml>. Acesso em: 3 jul. 2013.

FOUCAULT, Michel. Vigiar e punir - História da violência nas prisões. Tradução de Raquel Ramalhete. 20. ed. Petrópolis: Vozes, 1999.

GOMES, Isabella Monteiro. Trabalho do preso: premissas para o reconhecimento dos direitos trabalhistas e da relação de emprego. Revista de Direito do Trabalho, São Paulo, v. 144, p. 193, out. 2011.

GRAZIANO SOBRINHO, Sergio Francisco Carlos. A progressão de regime no sistema prisional do Brasil: a interpretação restritiva e a vedação legal nos crimes hediondos como elementos de estigmatização do condenado. Rio de Janeiro: Lumen Juris, 2007.

MAIOR, Jorge Luiz Souto. Curso de direito do trabalho: a relação de emprego. São Paulo: LTr, 2008. v. II.

et al. Dumping social nas relações de trabalho. 2. ed. São Paulo: LTr, 2014.

MELLO, Roberta Dantas. O renascimento do direito do trabalho no século XXI. In: REIS, Daniela Muradas; MELLO, Roberta Dantas de; COURA, Solange Barbosa de Castro Trabalho e justiça social: um tributo a Mauricio Godinho Delgado. São Paulo: LTr, 2013. p. 133-149.

MELO, Luís Antônio Camargo de. Premissas para um eficaz combate ao trabalho escravo. Revista do Ministério Público, Brasília, ano XIII, n. 26, p. 11-33.

MIRABETE, Júlio Fabbrini; FABBRINI, Renato Nascimento. Manual de direito penal: parte geral. 28. ed. São Paulo: Atlas, 2012. v. I.

MORAES FILHO, Evaristo. Temas atuais de trabalho e previdência. São Paulo: LTr, 1975. 
OLIVEIRA, Gláucio Araújo de. O trabalho penitenciário - Análise comparada Brasil/Espanha/Portugal. In: AZEVEDO, Andre Jobim de; VILLATORE, Marco Antônio Direito do trabalho: XIV Jornada Luso-Hispano-Brasileira. Curitiba: Juruá, 2010. p. 157167.

OLIVEIRA, Paula Julieta Jorge de. Direito ao trabalho do preso: uma oportunidade de ressocialização e uma questão de responsabilidade social. Revista Eletrônica da Faculdade de Direito da PUC-SP, São Paulo, v. 3, 2010. Disponível em: <http://revistas.pucsp.br/index.php/red/article/view/2801>. Acesso em: 2 out. 2014.

REALE JÚNIOR, Miguel. Instituições de direito penal: parte geral. Rio de Janeiro: Forense, 2003. v. II.

RIO GRANDE DO SUL. Tribunal Regional do Trabalho da $4^{\mathrm{a}}$ Região.Disponível em: <www.trt4.jus.br>.

RODRIGUES, Anabela Miranda. A posição jurídica do recluso na execução da pena privativa de liberdade: seu fundamento e âmbito. São Paulo: IBCRIM, 1999.

SARLET, Ingo Wolfgang. Dignidade da pessoa humana e direitos fundamentais na Constituição Federal de 1988. 5. ed. Porto Alegre: Livraria do Advogado, 2007.

SCAPINI, Marco Antônio Bandeira. Prática de execução das penas privativas de liberdade. Porto Alegre: Livraria do Advogado, 2009.

THOMPSON, Augusto. A questão penitenciária. 5. ed. Rio de Janeiro: Forense, 2002.

TRAMA, Vanessa Barbosa. Trabalho do preso. In: SANTOS, Jackson Passos; MELLO, Simone Barbosa.Contratos especiais de trabalho: estudos em homenagem a Óris de Oliveira. São Paulo: LTr, 2010. p. 252-263.

VAZ, Laurita. Trabalho penitenciário. Justiça e cidadania, Rio de Janeiro, v. 29, p. 16-19, dez. 2012. 